\title{
The Use of Impression Cytology in Ocular Surface Diseases
}

\author{
Oküler Yüzey Hastalıklarında İmpresyon Sitolojisinin Kullanımı
}

Gulay Turan ${ }^{1}$,

Pembe Oltulu²,

Meydan Turan ${ }^{3}$,

Refik Oltulu ${ }^{4}$

${ }^{1}$ Balıkesir University, Faculty of Medicine, Department of Pathology, Balıkesir, Turkey

${ }^{2}$ Necmettin Erbakan University, Meram Faculty of Medicine, Department of Pathology, Konya, Turkey

${ }^{3}$ Balıkesir Atatürk City Hospital, Department of Ophthalmology, Balikesir, Turkey

${ }^{4}$ Necmettin Erbakan University, Meram Faculty of Medicine, Department of Ophthalmology, Konya, Turkey

Geliş Tarihi/Received: 06 November 2018

Kabul Tarihi/Accepted: 10 December 2018

Address correspondence to: Gulay Turan, Balıkesir University, Faculty of Medicine, Pathology Department, Balıkesir, Turkey

e-mail: gulaytr@yahoo.com.tr

ORCID

Gulay Turan

https://orcid.org/0000-0002-3702-8811

\begin{abstract}
Öz
Impresyon sitolojisi (IC) selüloz asetat filtre kağıtları kullanılarak, oküler yüzeyin çeșitli bozukluklarının tanısına yardımcı olan basit, noninvaziv bir tekniktir. Bu bozukluklar arasında oküler yüzey skuamöz neoplazisi, kuru göz sendromu, limbal kök hücre eksikliği, spesifik viral enfeksiyonlar, vitamin A eksikliği, alerjik bozukluklar, konjonktival melanozis ve malign melanom yer alır. IC, oküler yüzey hastalığının teşhisine yardımcı olmak, oküler yüzey hastalığının patofizyolojisini daha iyi anlamak ve klinik çalışmalarda sonuç ölçütleri olarak kullanılmak üzere biyobelirteçler sağlamak için giderek daha fazla kullanılmaktadır.
\end{abstract}

Anahtar Kelimeler: Sitoloji, oküler yüzey, konjoktival hastalıklar, impresyon

\section{Abstract}

Impression cytology (IC), using cellulose acetate filter papers is a simple, noninvasive technique that aids in the diagnosis of several disorders of the ocular surface. These disorders include ocular surface squamous neoplasia, dry eye syndrome, limbal stem-cell deficiency, specific viral infections, vitamin A deficiency, allergic disorders, conjunctival melanosis and malignant melanoma. IC has been used increasingly to assist in diagnosis of ocular surface disease, improve our understanding of the pathophysiology of ocular surface disease, and provide biomarkers to be used as outcome measures in clinical trials.

Keywords: Cytology, ocular surface, conjunctival disease, impression

\section{INTRODUCTION}

Cytological examination has an important role in the diagnosis of conjunctival diseases. In order to perform cytological examination, a sufficient number of cells from the ocular surface should be taken. Cytology samples from conjunctiva can be obtained by conjunctival scraping method, pipette method, frotti method with cotton tip applicator and impression cytology method. Impression cytology, which was first described by Egbert and Thatcher in 1977 as a simple conjunctival biopsy, was defined as a safe, noninvasive method which can be easily repeated and used in the diagnosis and follow-up of changes in the cellular level due to various pathologies. Impression cytology is based on the principle of removing epithelial samples by gluing cellulose acetate filter paper to the conjunctiva surface in order to examine the cytological level of conjunctival surfaces. This method is used in the diagnosis of many disorders of the ocular surface due to the cell morphology of the conjunctival epithelium, the ratio of cytoplasm nucleus and especially the goblet cell density $(1,2)$.

\section{Sampling and Staining Method}

Impression cytology samples are taken using cellulose acetate filter papers with a pore size of 0.022 to 0.025 micrometer $(\mu \mathrm{m})$ without the need for any local anesthesia.

Cellulose acetate filter paper properties and use:

Cellulose acetate filter paper has two different surfaces, glossy and matte. These surfaces have different adhesion properties. When the regular and 
Table 1. Diseases using impression cytology

* Sjögren Syndrome

* Mucopolysaccharidosis

* Psoriasis

* Vitamin A deficiency

* Anorexia nervosa

* Trachoma

${ }^{*}$ Contact lens usage

* Keratoconjunctivitis sicca

* Xerophthalmia,

${ }^{*}$ Chemical burns

${ }^{*}$ Ocular surface squamous neoplasia

*Limbal stem-cell deficiency

${ }^{*}$ Allergic disorders

*Conjunctival melanosis and malignant melanoma

bright surface is touched to the conjunctiva, only the mucus is obtained. When the coarse and matt surface conjunctiva is touched, more cell samples are obtained (3). Cellulose acetate filter paper $3 \times 4 \mathrm{~mm}$ size, which has oval cut triangle shape, performed matte surface to the conjunctiva side, with the help of tootless forceps sligthly press the edge from $2 \mathrm{~mm}$ to the limb for 3-4 seconds (Figure 1A,B).

The filter paper consists of a system of spongy small gaps. The supernatant cell of the conjunctival epithelium is pressed into this cavity system during sample collection so that a tight relationship is established between the filter paper and the surface cell layer. When the filter paper is withdrawn from the conjunctiva, one or three cell layers of the epithelium remain on the filter paper (4).

\section{Fixation and Painting:}

Cellulose acetate filter papers containing wetted and conjunctival epithelial cells is fixed for approximately

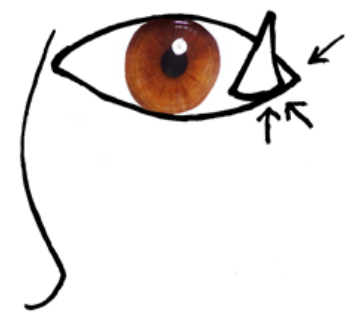

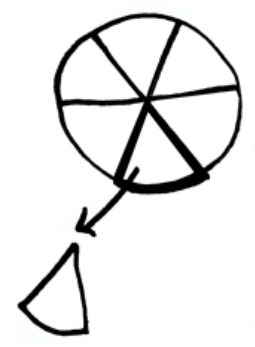

Figure 1. A Impression filter paper and sampling from the conjunctival surface.B Filter paper is cut into pieces of equal size and a piece is used.

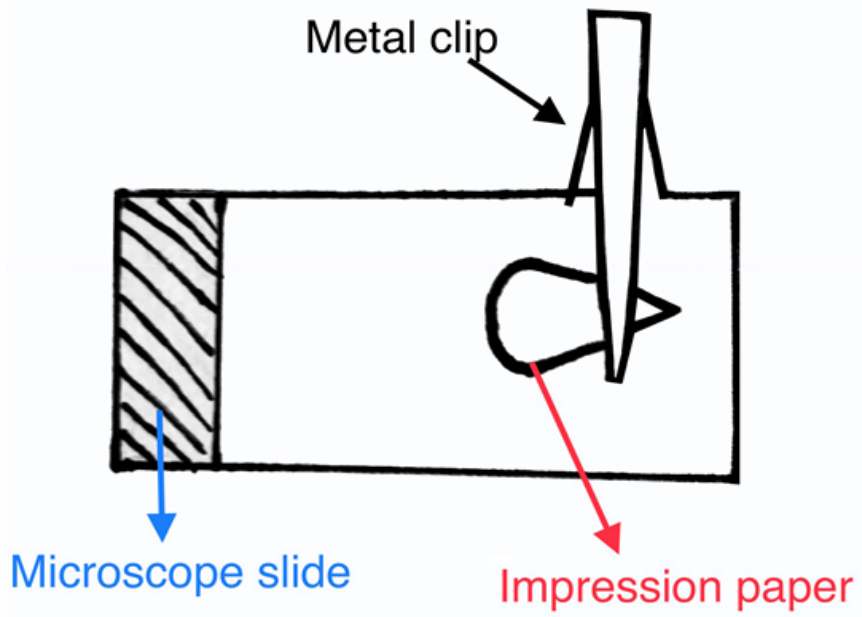

Figure 2. Each filter paper is attached to a microscope slide with a thin metal clip and the staining process is started.

10 minutes in a solution containing glacial acetic acid, $37 \%$ formaldehyde, and $70 \%$ ethyl alcohol in a 1:1:20 volume ratio. The left and right samples are stored in the refrigerator at $+4^{\circ} \mathrm{C}$ with cell samples facing up $(1,5)$. Papanicolaou or haematoxylin and periodic acid Schiff (PAS) stains are the commonly used stains for routine histological staining of impression cytology specimens. PAS staining protocol is shown in table 2 . Before painting, the cellulose acetate filter paper is fixed to the microscope slide using a metal clip (Figure 2).

After the painting process is finished, the cellulose acetate filter papers on microscope slide is closed via dropped entellan with cover glass (Figure 3).

Examination and Evaluation of Light Microscopy:

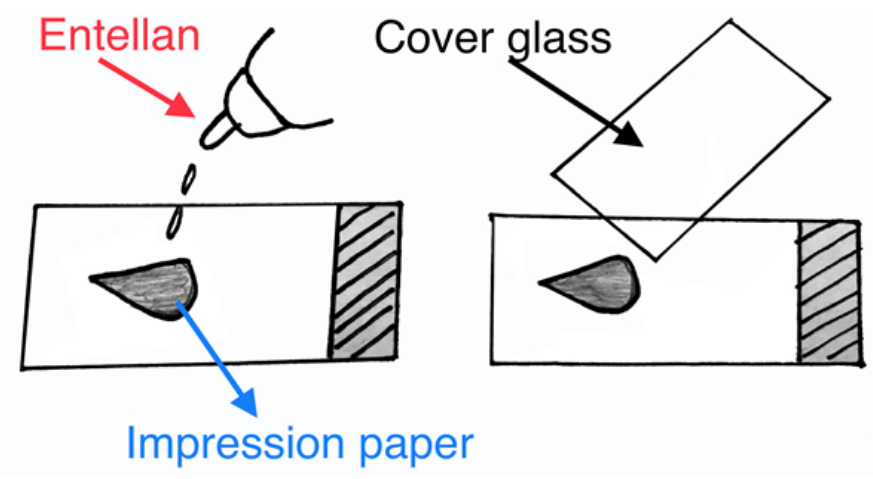

Figure 3. Stained paper (blue arrow), is placed on the microscope slide, dropped entellan (red arrow) on it and closed with a cover glass (black arrow). 
Table 2. Periodic Acid Schiff (PAS) staining protocol.

1. Washing with distilled water (5 min.)

2. Oxidation with $0.5 \%$ periodic acid ( $3-5 \mathrm{~min})$

3. Washing with distilled water (5 min)

4. Coloring with Schiff reagent (3-5 min)

5. Washing with distilled water (2 $\mathrm{min})$

6. Painting with haematoxylin mayer (1-2 min)

7. Washing with distilled water (2 min)

8. Washing with distilled water (2 min)

9. $70 \%$ alcohol $(1 \mathrm{~min})$

10. $80 \%$ alcohol (1 $\mathrm{min})$

11. $96 \%$ alcohol (1 $\mathrm{min})$

12. $\% 96 \%$ alcohol $(1 \mathrm{~min})$

13. Xylol (3 min)

14. Xylol (3 min)

15. Closing with Entellan.

The preparations are examined in the light microscope after painting. During this review;

a). Morphological changes in epithelial cells;

1. The presence of anisocytosis,

2. Nucleus cytoplasm ratio,

3. Existence of structural change (snake-like chromatin) in nuclear chromatin.

b) Changes in Goblet cell density; ascertainable.

Normally, goblet cells are of different density in different regions of the conjunctiva. Density is at the highest rate in nasal palpebral conjunctiva, respectively, temporal, palpebral, close to the fornix bulbar, close to the limb bulbar conjunctivas are in decreasing amounts $(3,6)$. For the counting of goblet

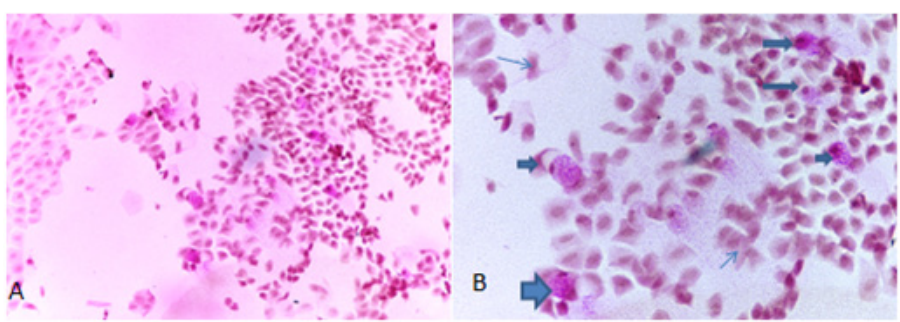

Figure 4 (A) Impression cytology of normal conjunctiva surface showing epithelial cells ( $\times 100$, periodic acid Schiff staining). (B) Impression cytology of the conjunctival surface showing reddish pink goblet cells ( $x 400$, periodic acid Schiff staining).

cells, random area is selected from PAS stained samples. The goblet cells falling into the $x 400$ magnification area (a microscope area of $0.19 \mathrm{~mm} 2$ at $\times 400$ magnification) are counted. The mean value is found by counting in 5 adjacent microscope fields. In this way, the number of goblet cells falling to $1 \mathrm{~mm}^{2}$ area is calculated. (Figure 4A-B).

Different staging systems can be used to examine cell morphology and goblet cell density by impression cytology in conjunctiva $(4,7)$ (Table 3 ). The most commonly used is the Nelson Staging system. In this classification; Stage 0 indicates normal cytology, Stage 1 early squamous metaplasia, Stage 2 and 3 indicate late squamous metaplasia with increasing intensity. In addition, inflammatory cells observed in impression cytology should also be recorded.

Table 3. Goblet and non-goblet epithelial cell characteristics of three main grading systems

\begin{tabular}{llll}
\hline Classification & Goblet cells ratio & Non-goblet epithelial cells & N:C \\
\hline Tseng & & Uniform size/form & $1: 1$ \\
Grade 0 & Moderate density & Mild enlargement & Moderate enlargement, \\
Grade 1 & Decreased density & Mattened (squamoid) & $1: 2-1: 3$ \\
Grade 2 & Absent & Markedly squamoid & $1: 4$ \\
Grade 3 & Absent & Shrunken cytoplasm & $1: 6$ \\
Grade 4 & Absent & Small, round & $1: 8$ \\
Grade 5 & Absent & Slightly larger, more polygonal & Nucleus may be absent \\
Nelson & Plump/oval, abundant & $1: 2$ \\
Grade 0 & Plump/oval, decreased number & $1: 3$ \\
Grade 1 & Smaller, poorly defined border, & & \\
Grade 2 & markedly decreased number & Larger, polygonal & $1: 4-1: 5$ \\
& Very few & Large, polygonal & $>1: 6$ \\
Grade 3 & Abundant & Normal & $1: 2$ \\
Adams & Slightly decreased number & Larger & $1: 3$ \\
Grade 0 & Decreased number & Larger & NS \\
Grade 1 & Very decreased number & Large, irregular & NS \\
Grade 2 & & & \\
Grade 3 & &
\end{tabular}

$\mathrm{N}: \mathrm{C}=$ Nucleus:cytoplasm. 
Three review articles on impression cytology of the ocular surface have been published in recent years. McKelvie (8) addressed the technical aspects of impression cytology, especially in reference to the user-friendly Biopore membrane device. She additionally addressed the application of impression cytology in diagnosing ocular surface squamous neoplasia. Calonge et al (9) provided a historical review of impression cytology technique, showing it to be a useful diagnostic aid for a wide variety of processes involving the ocular surface, while being minimally invasive. Singh et al (10) also underscored the ability of impression cytology to diagnose a wide range of ocular surface disorders and also stressed the importance of cell harvesting technique, as the number of cells obtained varies considerably depending on the methodology used.

Impression cytology is an easy to administer and non-invasive procedure. The ability of the clinician to take adequate cell samples and the proper transfer of the samples taken increase the reliability of the cytological diagnosis. In addition, a good staining is required for the pathologist to see the cells clearly. For some reason, although many ocular surface diseases have a practical and reliable result, they have not been widely used in clinics. Impression cytology should be used more widely in clinics to confirm clinical diagnosis.

Conflict of interest: Authors declare that there is no conflict of interest between the authors of the article.

Financial conflict of interest: Authors declare that they did not receive any financial support in this study.

Address correspondence to: Gulay Turan, Balıkesir University, Faculty of Medicine, Pathology Department, Balıkesir, Turkey e-mail: gulaytr@yahoo.com.tr Gsm: 05053123110

\section{REFERENCES}

1. Egbert PR, Lauber S, Maurice DM. A simple conjunctival biopsy. Am J Ophthalmol 1977;84:798-801.
2. Thatcher RW, Darougar S, Jones BR. Conjunctival impression cytology. Arch Ophthalmol 1977;95:678-81.

3. Gilbert JM, Weiss JS, Sattler AL, et al. Oculer manifestations and impression cytology of anorexia nervosa. Ophthalmol 1990;97:1001-7.

4. Nelson JD. Impression cytology. Cornea 1988;7:71-81.

5. Tseng SC. Staging of conjonctival sguamouse metaplasia by impression cytology. Ophthalmol 1985;92:728-33.

6. Saini JS, Rajwanshi A, Dhar S. Clinicopathological correlation of hard contact lens related changes in tarsal conjunctiva by impression cytology. Acta Ophthalmol 1990;68:65-70.

7. Nelson JD, Havener VR, Cameron JD. Cellulose asetate impression cytology of the ocular surface. Dry eye state. Arch Ophthalmol 1983; 101:1869-72.

8. McKelvie P. Ocular surface impression cytology. Adv Anat Pathol 2003;10:328-37.

9. Calonge M, Diebold Y, Sáez V, et al. Impression cytology of the ocular surface: A review. Exp Eye Res 2004;78: 457-72.

10. Singh R, Joseph A, Umapathy T, et al. Impression cytology of the ocular surface. Br J Ophthalmol 2005;89:1655-9. 